\title{
CIRCUMFLEX ADVANCEMENT IN PREKMURJE AND BEYOND
}

\author{
Marc L. Greenberg
}

\section{Introduction}

The advancement of the Common Slavic circumflex accent is generally considered a common Slovene innovation, one of the "rare linguistic phenomena that are characteristic only of Slovene and carried out on its entire territory" (Rigler 1986 [1973]: 122; cf. also Lencek 1982: 82).' The innovation is thus justifiably presumed to have taken place at around the time of the fall of the jers. Ramovš dates the circumflex advancement to a moment just after the fall of weak jers (1936: 55) and gives the absolute chronology as the 10th cent. AD (1950: 23). Stankiewicz claims that Slovene "extended the rule of lengthening and of the concomitant shift of stress from disyllabic words containing a weak jer to all words with an initial nonrising, long or inherently short $(o, e, z, b)$ syllable" (1986 [1966]: 38-39), implying that the process of the fall of weak jers was under way by the time the circumflex begance its advance. Kortlandt dates circumflex advancement and loss of weak jers concurrently: "The oldest specifically Slovene accentual development is the progressive shift of the stress from a falling vowel on to the next syllable. [...] At this stage, weak jers in medial syllables had already lost their stressability, cf. the gen sg. nohta of nohât. At the same time, an epenthetic vowel had already developed in such forms as vozal and rebâr" (1976: 2). Like Ramovš, Kortlandt dates the circumflex advancement to the 10th c. A.D. (loc. cit.). The present paper agrees in general with the simultaneous dating of the fall of weak jers and the advancement of the circumflex, although different relative chronologies will be proposed for different areas. Moreover, the discussion will reveal more about the way in which

1 A preliminary version of this paper, which is derived from my 1990 disserfion, tat was read at the Biennial Conference on Balkan and South Slavic Linguistics, Literatures and Folklore at the University of Chicago, April 9-11, 1992. I am grateful to Prof. Bill Darden (U. of Chicago) for his comments made at the Conference. I am also indebted to Prof. Willem R. Vermeer (U. of Leiden), who first pointed out some of the relevant Prekmurje facts (from Pável 1909), as well as to Prof. Tom M. S. Priestly (U. of Alberta) and three anonymous referees for their helpful comments on an earlier draft of the paper. Work on the paper began under the auspices of a Fulbright-Hays Dissertation Training Fellowship for 1988-89. Last, but certainly not least, thanks go to the Hall Center for the Humanities at the University of Kansas, which provided time and space to put the finishing touches on this paper in January 1994. 
circumflex advancement interacted with jers and Late Common Slavic vowel quantity in general on the eastern periphery of Slovene and the western periphery of Kajkavian.

As is well known, there are data that complicate the reconstruction of circumflex advancement as a Common Slovene innovation. One set of problematic data is found in the dialect of Resia, on the northwestern periphery of Slovene-speaking territory, which at first glance seems ambiguous with respect to circumflex advancement (see Bajec 1921-1922, Rigler 1972, Stankiewicz 1984-1985, Vermeer 1987). It has recently been shown by Vermeer that Resian, as well as the Zilja dialect, had advancement only in certain phonological environments. ${ }^{2}$ On the eastern periphery of Slovene and the western periphery of Kajkavian there are also dialects in which the advancement is not present in all of the expected forms, although the forms that fail to have advancement differ from dialect to dialect. This paper will discuss these (eastern Slovene and western Kajkavian) exceptions in terms of their structural motivation and attempt to determine what, if anything, they have in common. First, the question of whether the aberrant phenomena in the Prekmurje dialect can be attributed to morphological or phonological facts will be addressed. Second, evidence from other eastern Slovene and western Kajkavian dialects will be compared. Finally, a possible structural motivation for the phenomena will be discussed. ${ }^{3}$

\section{Prekmurje}

As elsewhere in Slovene, the Prekmurje dialect ${ }^{4}$ exhibits the advancement of stress one syllable to the right in words that were

2 Vermeer discusses the notion of advancement having taken place in six stages in westem Slovene and westem Kajkavian dialects within a section of his article prefaced by the remark that he "would like to end on a speculative note" (1987: 294). Specifically, Resian is thought to have had advancement only "(a) from weak jers onto open final syllables $(s z \hat{b})$; (b) from weak jers onto following syllables in all other cases (so bogomb)." Zilja proper is said to have had the innovation in those two environments as well as "(c) from full vowels in polysyllabic forms (sirô)" (op. cit.: 295-296).

3 Two disclaimers: (1) The presence or absence of circumflex advancement cannot be understood as the presence or absence of Sloveneness, as should be clear to linguists. The phenomena under discussion have been discovered on the northwestern and northeastem peripheries of Slovene and are thus in all likelihood archaisms, which expected on the periphery of any linguistic territory. (2) The paper is limited to the discussion of the phenomena in northeastem Slovene and Kajkavian.

4 The Prekmurje dialect, in its conservative varieties (which are assumed in this paper), distinguishes quantity (and not pitch) in stressed syllables. Numbered references to Prekmurje forms are for the village of Cankova as described in Pável 1909,1917 , and 1918. Citations from Pável's work is by page number only, as the page numbers do not overlap: $1909=$ pp. $1-148 ; 1917=$ pp. 165-187; $1918=$ 
circumflex- (initial-) stressed in Common Slavic. In all such instances the Common Slavic circumflex is reflected as a long vowel or diphthong, e.g., $\left({ }^{*} k d l o^{5}>\right)$ kol'ou 'wheel' (Pável 186), (*mè :so >) mäs'ou 'meat' $(45,57,63),\left({ }^{*}\right.$ òko $\left.>\right)$ ok'ou 'eye,' (*oba:dz $)$ ob'a:d 'horsefly' (16), (*rò.kQ >) rok'ou, 'hand' (acc. sg.) (16), måst'i: 'fat' (gen. sg.) (64), ('sù :ši:tz >) siš'i:t 'to dry' (sup.). In some instances Prekmurje has more consistent examples of advancement than other dialects and the literary language, which have partially eliminated the results of the advancement by analogical developments. For example, in Prekmurje the distinction in place of stress between nom. and acc. sg. in the feminine $a$-stems is maintained in the $" c_{4}$ paradigm, ${ }^{6}$ e.g., r'ouka 'hand' (nom. sg.) $(22,42)$ - rok'ou (acc. sg.) (16), n'ougd - nog'ou 'leg,' v'oda' - vod'ou 'water,' where the nom. sg. form displays the widespread Slovene retractions from final short stresses $\left({ }^{*} r Q: k^{\prime} a>\right.$ Standard Slovene ró:ka) and the accusative displays advancement. Both the »a« paradigm, e.g., c'esta 'road' (36, $51,53)$ - c'esto (14), kr'aiva 'cow' (27) - kr'àvo $(41,51,62)$, and the »b« paradigm, e.g., ž'änà 'wife' $(55,47,173,267)$ - ž'äno (272), b'äčka 'barrel' (46) - b'äcko, have merged with one another due to the retraction of stress in the »b « type (Standard Slovene krá.vakrá.vo, ž̌́:na-ž́:no; cf. Russian коро́вa-коро́вy, женá-женy). Elsewhere in Slovene this type has tended to merge with the "a« and/or "b" paradigms (Jaksche 1965: 54-55), cf. Standard Slovene róka - $r$ śko alongside the permissable variant ró:ka - rokd:: ${ }^{8}$

pp. 263-282. Cankova material without page references is from the author's field notes). Prekmurje material from the village of Martinje is from the author's field notes.

5 The suprasegmental marks in this paper should be read in the following way: the grave accent (a) marks falling intonation; the acute (á) marks rising; the foot mark to the left of the vowel ('a) marks place of stress in the absence of phonemic pitch. Distinctive length is marked by the colon (a:). Forms directly quoted within prose text are preserved with their original diacritic marks.

6 The designations »a «, »b $\alpha$ and $» c \ll$ refer to the well-known classification of accentual paradigms of Stang 1957.

? The length in the nom. sg. is by analogy with rouka.

8 Moreover, in Prekmurje the wc« paradigm a-stems types have become the model for neuter nouns that have shifted to the a-stem declension, e.g., v'ï:ja 'ear' vih'ou (5); gn'eizdd (17) - gnizd'ou (17)/gn'e :zda (37) - gnezd'ou (37). These forms and the like have been misinterpreted by Junkovic (1972), who claims that a form such as gnezd'ou proves that the circumflex advancement was late in Prekmurje. The explanation rests on the assumption that circumflex advancement, having applied to an originally acute-stressed form (cf. Standard Slovene gné:zdo, Russian гнездо́), must have occurred after pitch distinctions were lost (1972: 201-202). This can hardly be the case, since such a rule would predict **zvezd'a:; 
Advancement can be observed equally in nouns, e.g., d'äs'e:n 'autumn' (39), gosp'oud 'Mister' (11), im'e: 'name' (5, 42), koc'e:n (37, 39), kok'ouš 'hen' (62), mäd'ü: 'honey' (gen. sg.) (4l, 56), pom'ouč 'help' (169), pråh'ü: 'dust' (gen. sg.) (56), såd'ü: 'fruit' (gen. sg.) (56), väč'e.r 'evening' (10); verbs, e.g., bil'ou 'was' (neut. sg.) $(3,12,61,67)$, bil'a: 'were' (masc. du.) (271), billi: 'were' (masc. pl.) (275, 276), dål'ou 'gave, put' (neut, sg.) (52), god'illo sä 'was happening' (neut, sg.) (266), når'oudo sä 'was born' (masc. sg.) $(18,69)$, odg'ouvoro 'answered' (masc. sg.) (19), or'åo 'was plowing' (masc. sg.) (19), pog'oudilå sä 'agreed' (masc. du) (174), smid'a:lä sä 'laughed' (fem. pl.) (264); adverbs cil'ou 'even' (53), dom'ou 'homeward' (46, 142), lip'ou 'good, fine, beautiful' (53), mog'ouče (184), nat'ou 'then' (246). Prekmurje is also conservative with respect to the preservation of alternations brought about by the addition of proclitics, e.g., in prefixed noun phrases na d'e:sko 'onto a board' (acc. sg.) (46), z d'oumi 'from home' (gen. sg.) (172), z $n^{\prime}$ ouči (gen. sg.) 'out of the night' (46), s p'e:či (gen. sg.) 'from the oven' (172).

In certain Prekmurje words the stress is found on the first syllable, that is, it is not advanced where advancement would be expected. Pável cites a number of examples in the I-participle of prefixed verbs, most of which are $e$-theme verbs of the $"$ « accentual paradigm, e.g., d'oubo 'received' (masc. sg.) $(44,53)$, d'oubilo (neut. sg.), (180), d'oubili (masc. pl.) (53), n'a:bro 'gathered' (masc. sg.) (13, 19, 175), n'a:püu sä 'became drunk' (masc. sg.) (18, 19), n'a:spo sä 'slept enough' (13, 19), n'a.zvo 'invited' (13), 'oudro 'flayed' (24), p'oudro 'knocked down' (24), p'ouzvo 'called' (19, 276), p'ouzvåli (masc. pl.) (266), p'oužro 'swallowed' (24), pr'e:bro 'picked through' (19), pr'e:dro 'pierced' (24), pr'e:što 'read, counted through' $(41,175)$, pr'e.žgo 'burned through' (41), sp'oumro 'died' (24), z'a:spo 'fell asleep' $(14,19), z$ 'a.vro 'began to ferment' (24), zg'oudilo sä 'happened' (neut. sg.) $(167,177,267,271), z$ 'oudro 'plucked out' (24), z'ouro 'plowed' (19), z'e:bro 'chose' $(19,41)$, z'e.pro 'locked out' (19), z'e.zvo 'provoked' (19). (For convenience, the phenomenon in the l-participle will be referred to further as the "n'a:brou type.") There is a small number of examples outside of the

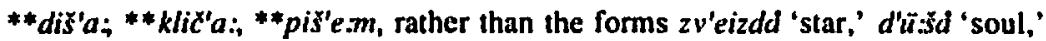

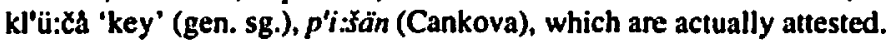

${ }^{9}$ In Cankova, stressed long vowels are regularly shortened in syllables closed by a sonorant or the reflex of a sonorant in the case of $-1,-o /-u$. 
l-participle, e.g., l'äiko 'can, may' (44), t'eilo 'body' (17), gl'a:sno 'loudly'; as well as doublets: l'eipo (142)/lip'ou (34, 53, 241), z'a:to $(5,12,148)$ /zat'ou $(2,244)$ (for further examples see 78 ).

The question thus arises: in the instances where circumflex appears not to have taken place, is the place of stress a retention or innovation? The number of examples outside of the l-participle lacking advancement is too small to deal with decisively; therefore, the question of retention versus innovation will have to be answered on the weight of the evidence from the 1-participle together with comparative evidence from outside the Prekmurje dialect.

However, a few words can be said about the non-l-participle types. The stress placement in the word t'eilo may have been influenced by the derivative t'eilovo, na t'eilovo 'Corpus Christi' (17); moreover, the non-motivated form would likely have been heard frequently in a liturgical (Croatian) context, where it would have had initial stress. The Prekmurje adjective as a rule shows no stress-placement alternations whatsoever, thus, it must be assumed that leveling on the basis of the long form has occurred (as virtually everywhere in Slovene), e.g., l'eipi (nom. sg. masc.) (53), l'eipa (nom. sg. fem.) (53), l'eipo (nom./acc. sg. neut.) (53), l'eipogå (gen. sg. masc./neut.) (268). It is conceivable then, that doublets of the type l'eipollip'ou may have arisen due to confusion of the adjectival stress with the adverbial. Nevertheless, this argument cannot hold for the doublet $z^{\prime} a . t o / z a t^{\prime} o u$, since there is no corresponding adjective; the argument would wear thin with l'äiko, as its formal relative l'äiki, $-a,-o$ 'light, easy' (44) cannot be viewed as semantically connected. In any case, standard Slovene has three accentual possi-bilities in bisyllabic adjectives of this type: teža :k (<

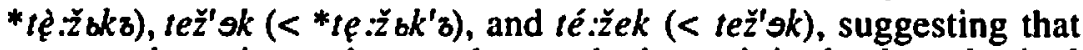
accentual variants have obscured the original phonological development here. Therefore, this evidence must be left aside as ambiguous. Unfortunately, this shifts the burden of proof inordinately onto the evidence of the l-participle.

\section{The l-Participle in Prekmurje}

\section{Possibility 1: Attraction or Retention of Stress on the Prefix?}

The vast majority of the I-participles that show initial stress are prefixed. It might therefore be surmised that the prefix has something to do with the stress falling on this syllable. However, many prefixed forms have circumflex advancement as expected, e.g., fćti:no (< * $v \not \grave{c} i: n i: l z)$ 'did' (masc. sg.) (81), nåk'ouso 'mowed a certain amount' (masc. sg.) ( 11,81$)$, nåp'outo sä 'headed somewhere' (178), när'oudo sä 'was born' $(18,69)$, odg'ouvoro 'answered: (19), 
pod'oujo 'milked' (81), poz'e:bo 'became chilled' (35, 38), pog'oudilå sä 'agreed' (masc. du.) (174), prägr'eišo 'commited sin' (81), vm'ouro (< *vòmori:lz) 'killed' (81), zad'a.vo 'choked' (81). The simplex forms corresponding to these also have the shift, although the stress falls on a different syllable than in the prefixed forms, e.g., čin'üu 'was doing' (81), dav'üu 'was choking' (81), dog'ïu 'was milking' (81), god'i:lo sä 'was happening' (neut. sg.) (266), griš'üu 'was sinning' (81), kos'üu 'was mowing' (81), mor'üu 'was killing' (81), rod' lïu 'was bearing' (81); the trisyllabic simplex-stem govor'üu 'was speaking' (masc. sg.) $(19,81)$ displays a reinterpretation of the advancement as stem-final stress on the model of bisyllabic stems, cf. said'üu 'was planting' $(19,81)$, nas'a:do 'planted' (81). In the Prekmurje dialect of Martinje (where stressed quantity has been replaced by new vowel quality; for details see Greenberg 1993) the same distribution is found, e.g., kos'yu 'was mowing' (masc. sg.), kos'yli (masc. pl)—pok'aosili 'mowed' (masc. pl.); rod'yls'gave birth' (fem. pl.) -nur'aodo si 'was born.' The original distribution of stress in these forms is remarkably archaic, i.e., one would have expected contamination from the simplex stress pattern to the compound, as in standard Slovene (e.g., kosi.u, kosi:la, kosi:li $\longrightarrow$ pokosi:u, pokosí:la, pokosi:li). Therefore, in the n'a:bro, n'a:brali type, retraction to or retention of the stress by the prefix cannot be the explanation.

\section{Possibility 2: Phonetic Retraction?}

It has been suggested that instances of initial stress where second-syllable stress is expected can be explained in two ways: (1) the prefix or preposition has attracted the stress, e.g., $z^{\prime}$ a.vora ${ }^{10}$ 'brake,' pr'i nas (Standard Slovene zavòra, pri n'as) (against which an argument was lodged above); or (2) Ramovš's phonetic retraction (the "tertiary retraction," on which see the discussion below) of the type oko: > 'oko has taken place. Both of these explanations have been invoked to explain the unexpected initial stresses in Prekmurje and other eastern Slovene dialects (see, for example, Zorko 1989: $241,251) .11$

to The z'a.vora type has been explained by Vermeer (who attributed the discovery of the rule to Stjepan Ivకic) as a retraction of neo-circumflex onto pretonic long vowels, which results in a rising tone in the pitch-distinguishing dialect of Bednja (Kajkavian) (for details see Vermeer 1978: $375-377$ ). Since this retraction fails to retract advanced circumflexes (which have occurred also in Bednja), it is not directly relevant to the present discussion.

11 The description of the Žetinci dialect as presented by Zorko (1989) is bizarre, as it contains features which are typical, on the one hand, of Prekmurje and of 
A phonetic retraction from formerly advanced circumflexes was identified by Ramovక (1950: $21-22)$. This retraction, now generally referred to as the "tertiary retraction" (tretji umik), was known (or thought) at that time to have occurred in the Savinja Valley, eastern Carinthia, Zilja, Rezija, Venetian Slovene, and Crni vrh with the Poljana dialect (Rovte). It has also taken place in the Kostel and Bela Krajina dialects. As Ramovš noted, this innovation is relatively recent: it "cannot be dated to a period before the 18th c." (21). His reasoning proceeds from the fact that the areas in which it is found are not connected geographically and that the retraction has taken place after relatively recent local innovations, such as akanje, e.g., 'aku: (< *okd:) 'eye' (Črni vrh), lá:po (<*lepò:) 'good, fine, beautiful' (Rož). In tone-distinguishing dialects, such as Carinthian, the retraction results in a rising pitch on the initial syllable. In the Crmi vrh and Poljana dialects of the Rovte group and the Kostel dialect the place of stress has become initial, the stress is distinctively short (even if the vowel had been long in Common Slavic), and the post-tonic syllable has remained distinctively long, e.g., Delač (Kostel dialect) z'obje: 'teeth,' v'iče.r 'evening,' $m$ 'esu: 'meat,' l'ipu.: Thus, this stress retraction is, as Ramovš stated, a relatively recent innovation with different results in the various areas that it occurred and it takes place well after the loss of distinctive unstressed vowel quantity. Therefore, if this stress retraction has taken place in Prekmurje, and its cause is similar to that of other Slovene dialects, it should have been a relatively recent phenomenon whose phonetic results would look very different than that of an archaism dating to a time close to the emergence of early Slovene from Late Common Slavic. Since Prekmurje is not a pitch-distinguishing area, in which case a rising tone in the initial syllable would provide reasonably good support for a stress retraction, the matter will have to be discussed on indirect evidence.

Prlekija, on the other. For example, the description cites diphthongal reflexes of long $z$, as is characteristic of Prekmurje and (so far) unknown in Prlekija, e.g., gr'eih 'sin,' p'eisek 'sand,' mes'ou, m'ouc 'strength' (243). The masc. sg. form of 1-participle displays the change $-1, a$, which is known only in part of Prlekija and not at all in Prekmurje, e.g., n'esa 'carried,' h'oda 'walked,' zd'igna 'raised' (244). The Radgonski kot, as it turns out, is home to speakers of relatively recent provenience from both Prekmurje and Prlekija. It is possible and even common for Prekmurje and Prlekija dialect speakers to coexist in a single household, in which case they appear to keep their dialects mostly distinct (for details see Križman 1987). It is therefore strange that Zorko's description of Žetinci (precisely the village referred to in Križman's work) should implicitly treat the village as having speakers who share a single uniform code. 
Prekmurje shares with the bulk of the Slovene dialects stress retractions from final syllables onto the preceding syllable that have tended to eliminate final-stressed words in individual dialects (for details see Ramovక 1929, Greenberg 1987). These retractions include the general Slovene retraction onto Common Slavic long syllables, e.g., gl'a.va 'head' (Pavel 1909, 1917, 1918: 11, 36), gr'e:då 'vegetable garden' (42), s'oused 'neighbor' (54), v'einäc 'wreath' (38) (cf., R. головá, грядá, сосе́d, вене́u); the widespread Slovene dialectal retraction onto Common Slavic short syllables $(e, o)$, e.g., m'ädved 'bear' (54), p'oslo 'sent' (masc. sg.) (19, 269), prn'äso 'brought' (masc. sg.) (173, 186), råsp'otro 'broke irreparably' (masc. sg.) (24), v'odå 'water' $(27,37,269)$, ž'änå $(47,55,173,267)$ (cf., R. медве́d, посла́л, принёс, принесла́, водá); as well as the less widespread Slovene dialectal retraction onto the reflex of strong jer, e.g., m'äglà 'fog,' (8, 46), s'ämlo 'ground' (masc. sg. l-participle) (19), st'äbär 'pillar' (33) (cf. Russian мzлá; Standard Slovene zml'eu, $\left.s t 9 b^{\prime} s r\right)$. Long syllables in final syllable have not been retracted, e.g., dob'i:š 'get' (2nd. sg.) (265), (h)idobri'a:k 'rascal' (51), jin'a:k 'hero' (52), näs'e:n 'carry' (1st. sg.) (39), posiš'i: 'dries' (3rd. sg.) (50), råzbij'a.č 'noisemaker' (31), väč'e.r 'evening' (10, 40, 280). As a result of these processes, short stresses in the Prekmurje dialect do not occur in the final syllable of polysyllabic words (see Greenberg 1987: 180,181 ).

As is clear from the examples above, the Common Slavic vowel quantity was preserved in the pretonic syllable until the retractions took place. Thus, Common Slavic long vowels that have received stress by retraction are realized as long, e.g, *sQ:sêddo > s'oused; those that were short (*žen'a > žänd) or reduced (*mbgl'a> m'äglä) are realized as short. If a stress retraction is to account for the instances of intial stress in words where advancement is otherwise expected, there are two possibilities for the distribution of quantity in the newly stressed vowel: (1) if the retraction was contemporary with the other stress retractions that took place in Prekmurje, the quantity of the stressed vowel should reflect the quantity found in Common Slavic; (2) if the retraction is relatively recent, as predicted by Ramovš, then it is very likely that pretonic quantity would have been lost (i.e., neutralized in favor of shortness) before the retraction, in which case the stressed vowel would be short after retraction. However, neither of these distributions holds, since all of the instances of initial stress under discussion here are long-stressed without regard to the Common Slavic quantity of the vowel, e.g, they may be from long vowels (n'a:bro, n'a:püu sä, n'a:spo sä, n'a.zvo, pr'e:bro, pr'e:dro, pr'e:šro, pr'e.žgo, z'a:spo, z'a.vro); short vowels 
(d'oubo, d'oubil, d'oubili, 'oudro, p'oudro, p'ouzvo, p'ouzvali, p'oužro, sp'oumro, zg'oudilo sä, z'oudro, z'ouro); or reduced vowels (z'e:bro, z'e:pro, z'e.zvo). It must be concluded then, that these examples of initial stress are not due to a phonetic retraction.

\section{Possiblity 3: Retention of the Common Slavic Place of Stress?}

Characteristics of the set of initial-stressed I-participles is that most examples consist of a prefix followed by a root with a weak jer, e.g., nà:-bbralz, pò-zъva:li: (> n'a:bro, p'ouzvåli). It might be assumed then, that the jer in the second syllable prevented the advancement of the circumflex. If this were the case, it would lead to the assumption that weak jers were still present at the time of the forward shift. This assumption has two immediate advantages: (1) it dates the shift to a period early enough to be Common Slovene, i.e., around the 10th cent. AD, as is generally assumed; (2) it is in accord with the reason why a form such as $z g^{\prime}$ oudilo sä has become initial-stressed: the stressed weak jer in the prefix was present at the time it ceded the stress to the following full vowel, and the weak jer in the prefix was subsequently lost (zògodi:lo > zgò:di:lo).

There are more types that behave like $z g^{\prime}$ oudilo sä, including the simplexes of the n'a:bro type: (*zzvali. $>$ ) zv'a:li 'tcalled' (masc. pl.) (Pável: 4); Martinje dialect (*bòra.li: >) b r'ali 'they picked,' (*sòpa:li: >) sp'ali; and words like (*zòpově:dz >) s p'ouvit 'confession' (Pável: 186), (*zölodè.jo >) zl'oudi 'devil' (54) (cf. Standard Slovene izpòved, zlö:dej; SC ispovije:d); as well as prepositional phrases (*sż peči: >) s p'e:či 'out of the oven' (172), (*zo domu: >) z d'oumi 'from home' (172). Simplex l-participles without weak jers in the root have the ictus in the second syllable as expected, e.g, bil'ou 'was' (neut. sg.) $(3,12,61,67)$, bil'i.i (masc. pl.) (273, 275, 276), dål'ou 'gave' (neut. sg.) (52), or'ao 'was plowing' (masc. sg.) (19), smid'a:lä sä 'laughed' (fem. pl.) (264); Martinje bil'ao 'was' (neut. sg.), bil'y (masc. pl), bil' $\varepsilon$ (fem. pl), merl'y 'died,' (masc. pl.) or'ali, bod'ali sa ' were afraid,' pil'y 'drank.'

So far the discussion has suggested that the presence of a weak jer has caused the retention of initial stress in the set of 1-participles. However, this explanation does not help with forms such as d'oubo, d'oubili, n'a.püu; Martinje d'aobo, d'aobili, d'aobila (masc. du; cf. fem. sg. dob'yla), 'aodo 'sold' (masc. sg.), 'aodali, n'apili sa. These can be ascribed to analogical developments, since there is only one model for analogy. The model is the prefixed jer-root l-participles with the "c " (mobile) stress pattern, which is the only type in which there is an alternation between the masc. sg., neut. sg., masc. pl., fem. pl. (all initial-stressed-examples above) and the fem. sg. 
(retracted stress onto the pre-final vowel, e.g. Martinje $b^{\prime} y l^{\circ}$, nabr'ala, pobrala, porzv'ala 'called'); cf. also dob'i:la (267); Martinje dob'yla, nap'yla sa.

It must be concluded that the presence of a weak jer in prefixed jer-root 1-participles has blocked the advancement of stress in the Prekmurje dialect, in other words, forms such as p'ouzvo, p'ouzvaili retain the Common Slavic place of stress. However, the matter cannot be left there, since as an isolated phenomena the non-advancement is of little use for understanding the early innovations in the Slovene prosodic system. We will now turn to some comparative evidence from other dialects in the neighborhood of Prekmurje, in eastern Slovene and western Kajkavian, before returning to a final structural argument that makes sense the notion of non-advancement of the circumflex.

\section{Beyond Prekmurje}

Prekmurje is not the only dialect in eastem Slovene or western Kajkavian to have instances of non-advancement of the circumflex. The evidence points to other dialects where circumflex advancement has been inhibited by phonological conditions. Though the evidence is stronger or weaker depending on the available descriptions (the Slovene-Kajkavian border areas are notoriously poorly described in the literature), the general picture that emerges is coherent, as will be seen below. (See the map, p. 82).

\section{Haloze}

Haloze (south of Prlekija, between the Dravinja river and its continuation in the Drava river, and the Croatian border) is one of the least well attested Slovene dialects. ${ }^{12}$ However, the results of some recent fieldwork done by Zorko (1991, 1993), taken together with earlier work (Kolarič 1964/3), give the strong impression that the

12 See, for example, Ramovš's ten-line description in 1935: 181, which contains a list of eight features, illustrated by altogther seven unaccented forms.

13 Kolarix's description is hardly the paragon of responsible fieldwork. His informants were students of the Ptuj Gymnasium from the villages of Cirkulane, Leskovec, Podlehnik and Svece; a hunter from Veliki Vrh pri Borlu; an illiterate woman from Brezova Gora (Croatia) who had married and lived in Slovenske gorice for nearly 25 years, rarely having retumed to her native village. Thus the first four are suspect because of higher education and the woman from Brezova Gora because of her extensive contact with the Slovenske gorice dialect. Kolarix himself admits that all but the woman from Brezova Gora/Slovenske gorice had noticeable influence of standard Slovene in their speech. In addition, two of the students-Kolaric does not say which ones-come from migrant families, one originating in lower Prlekija, the other from near Trieste (1964: 397). To make matters worse, Kolarix fails to identify the village provenience of all but a few of the forms he cites. For these reasons, the material should be considered somewhat 
facts of circumflex advancement here are very similar to that of Prekmurje. Two groups can be distinguished:

(1) As in Prekmurje, the $p^{\prime}$ 'ouzvo type remains intial-stressed: z'ebrali so se 'they gathered' (Zorko 1991: 56), p'ouggali 'they lit' (56), (examples from "the easternmost part of Haloze" [Zorko 1991: 55]); zẹ:brali so se (Zorko 1993: 205). ${ }^{14}$ The analogical type d'oubili

less than reliable unless it is confirmed by similar forms in later work by Zorko (1991, 1993). Unfortunately, Zorko, too, has also failed to identify the exact provenience of most of her forms; she refers vaguely to "western," "central" and "eastem" Haloze.

14 The examples zechrali so se (Zorko 1991: 56) and zẹ:brali so se (Zorko 1993: 205) may be from the same village. In 1991 the example appears under the rubric "Eastern Haloze dialects with a monophthongal vocalic system," which apparently refers to the villages of Zavrz, Turski Vrh, Veliki Vrh, and Belski Vrh (56). In 1993 the example appears in a section that describes the "accentual situation" in "the east and part of the center" of Haloze (205), though there is a hint in the article's summary that the material for this area is represented by Velikj Vth (207). - According to Zorko (1991: 55; 1993: 205), the rising pitch ("nizka intonacija") in eastem Haloze occurs only in short syllables. This pitch reflects Common Slavic old (se je jęlo 'it was caten,' gọba 'mushroom,' rézati yo cut') and neo-acutes (Vóla 'wll,' méša 'Mass'), as well as retractions onto Common Slavic shor (kọza 'goat,' glọboko 'deeply') and long vowels (rástava 'exhibit,' záčimba 'spice'; kü̈pila 'she bought,' p(sala 'she wrote' [1991: 56]) (all examples, unless otherwise noted, from-1993: 205). It is very possible that this area is pitch-distinguishing; compare, for example, the 120-year-old statement by J. Pajek, published in Zora in 1875 (cited from Kolaric 1964: 396): "Človek umega jezika je Haložan; poskakuje namrec pri vsakej tretjej ali cetrtej besedi z glasom na visoko in potem zopet nazaj; proti koncu stavka pa besede neprijetno zateza. To nenavadno, nenaravno naglasanje je krivo, da ga težko razumes, in te lahko smeh posili, dasi drugace dobro slovenscino govori, in le nekoliko sosednje hrvašcine vplete" (A man from Haloze is of quick tongue; that is, every third or fourth word his voice jumps up high and then down again; at the end of a sentence the words are unpleasantly stretched. This unusual, unnatural accenting is odd, so it is hard for you to understand and it can make you laugh, although otherwise he speaks good Slovene with only a little influence from neighboring Croatian). This statement may or may not refer to word-level intonation. Moreover, that eastern and central Haloze, as opposed to all of eastern Slovene (which are to date considered to have lost pitch distinctions), retain pitch distinctions is not surprising, since these areas are closely connected geographically to the valley in which the pitch-distinguishing dialect of Bednja lies. However, it is typologically unlikely that pitch distinctions occur only in short syllables and, even if true, it is very unlikely that such a system would have persisted since the time of the South Slavic shortening of the old acute. Furthermore, the shortening of Common Slavic long vowels that have become "short rising" through "retraction," a phenomenon that would be unique in eastem Slovene, remains to be explained. Therefore the jssue of whether pitch and/or quantity distinctions exist (and, if so, in what relationship to each other) in Haloze must remain open. Until it is possible to 
(1991: 60; 1993: 206) is also attested. Other prefixed »c« stressed 1-participles without jer-roots have advancement, e.g., pok'osili 'mowed' (masc. pl.) (56), pop'isili 'they drank' (66); advancement is also found in unprefixed l-participles, e.g., bil'i:i 'they were' (65), kos'ïo 'was mowing' (masc. sg.) (57), or'å: 'plowed' (64), sišili 'dried' (57). The adverb i'e :ško 'heavily' (Kolarič 1964: 398), which contained a weak jer in the second syllable (<*tè ž̌bko; cf. Standard Slovene tešk' $\partial$ :), does not have advancement. In the absence of a weak jer circumflex advancement has taken place as expected, e.g., lep'o: 'beautifully' (Zorko 1991: 56; 1993: 205).

(2) In all other environments Haloze shows circumflex advancement consistent with standard Slovene, e.g., (a) from a short open to a short open syllable: kol'ou 'wheel' (Kolarix 1964: 399, 401), ok'o:/ok'o:u 'eye' (399), 'o:ko/ọ:ka's (400); pep'e:la 'ash' (gen.sg.) (Zorko 1991: 56), pok' osili (56); (b) short open to long open syllable: im'e: 'name' (Zorko 1991: 56), mes'ou (Kolaric 1964: 398), otro:bi 'chaff' (Zorko 1991: 56); (c) long open to long open syllable: l'e:saAis'a: (Borl) 'wood' (gen. sg.) (Kolaric 1964: 400), kost'i: 'bone' (gen. sg.) (Zorko 1993: 205); (d) short open to short closed syllable: kok'out 'rooster' (Zorko 1991: 67), več'e.r 'evening' (56); (e) short open to long closed syllable: okr'ọ:gl/okr'ougd 'round' (masc. sg.) (Kolarič 1964: 398), gol'o.p 'pigeon' (Zorko 1991: 56; 1993: 206); (f) long open to long closed syllable: des'e.t 'ten' (63), dev'e.t 'nine' (63), sušit. 'dry' (supine) (Kolaric 1964: 398).

The facts so closely mirror those in Prekmurje that it is very likely that in Haloze, too, the weak jer in the second syllable was the one condition under which circumflex advancement failed to occur.

\section{Prlekija 1: Radomerščak}

Radomerščak lies about eight kilometers to the west of the Slovene-Croatian border, roughly halfway between the towns of Ljutomer and Ormož. It is a dialect that contains more of the features said to be typical of Prlekija dialects than that of Središce (Ramovక̌

clarify these issues, only the place of stress in Zorko's material can be considered to have a degree of reliability.

is As mentioned above, it is impossible to know the precise provenience of these forms. Nor is the gender or case (to say nothing of any paradigmatic information) of the form of 'Q:ka clarified (this could belong to the feminized neuter type, the case forms of which are stressed differently than the mobile neuters). Thus no explanation can be posited for this variation until more detailed information becomes available for Haloze. 
1935: 177-182), discussed below. In terms of circumflex advancement, the Radomerščak dialect behaves similarly to Prekmurje. Examples are from Zorko 1992.

(1) The reflex of the Common Slavic circumflex is found in the first syllable if (a) the first syllable was a weak jer, e.g., sp'ozvali 'invited' (masc. pl.) (465), zg'ọdilo se je 'happened' (neut. sg.) (465), ${ }^{16} 2 n^{\prime}$ o.pili 'drank' (465); or (b) the second contained a weak jer, e.g., l'ehko 'can, may' (475), n'abrali 'gathered' (465), 'obrali 'picked' (465), z'ẹbrali 'chose' (465).

(2) The advancement of the Common Slavic circumflex occurred in all other phonological environments, e.g., (a) from a short open to a short open syllable: im'ẹ: 'name' (465), neb'o: 'sky' (469), ok'o: 'eye' (464), pok'osja (< *pòkosi:l z) 'mowed' (465), pros'ọ: 'millet' (469); mes'o: 'meat' (465); (b) short open to long open syllable: kos'ili 'they mowed' (475), noč'i: 'night' (gen. sg.) (469), peč'i: 'oven' (gen. sg.) (469), otr'ọ:bi 'chaff' (465), pos'ü:ša (< *pòsu:šilz) 'dried' (465); (c) long open to long open syllable: pil'i: 'drank' (masc. pl.) (471), siš'ili 'dried' (475); (d) short open to short closed syllable: jes'ẹ:n 'autumn' (465), pep'e:l 'ash' (465); (e) short open to long closed syllable: gol'ọ:p 'pigeon' (465).

\section{Bednja (Zagorje Kajkavian)}

As has been pointed out by Vermeer, the Bednja Kajkavian dialect has a number of forms in which circumflex advancement has taken place as well as a number of forms in which the Common Slavic place of stress has been maintained (Vermeer 1979: 366). ${ }^{17}$ As the Bednja phenomena, both the regular and analogical developments, have been thoroughly discussed in Vermeer 1979 (366-375), the reader is referred to this source for details. Here the facts of the phonologically regular developments will be summarized for the sake of comparison. Page references are to Jedvaj 1956.

${ }^{16}$ The difference in the marking of length in the first two examples (which represent identical phonological conditions), as well as a number of other examples of unexpected and inconsistent vowel quantities in the article (e.g., kos'i:li[471] and kos'ili 'they mowed' [475]; siš'ili 'they dried' [471] and sišili [475]), casts doubt on the reliability of Zorko's perception of quantitative oppositions. For this reason the quantity markings (represented here faithfully to Zorko's transcription) should not be considered definitive. Compare also the remarks above regarding Zorko's description of Haloze.

17 Vermeer credits M. Pesikan as the first to point out the phenomenon in the latter's 1963-1964 review of Jedvaj 1956 (Jubnoslovenski filolog 26: 556-580). The forms cited in the present paper are regularized based on the observations made in Vermeer 1979. 


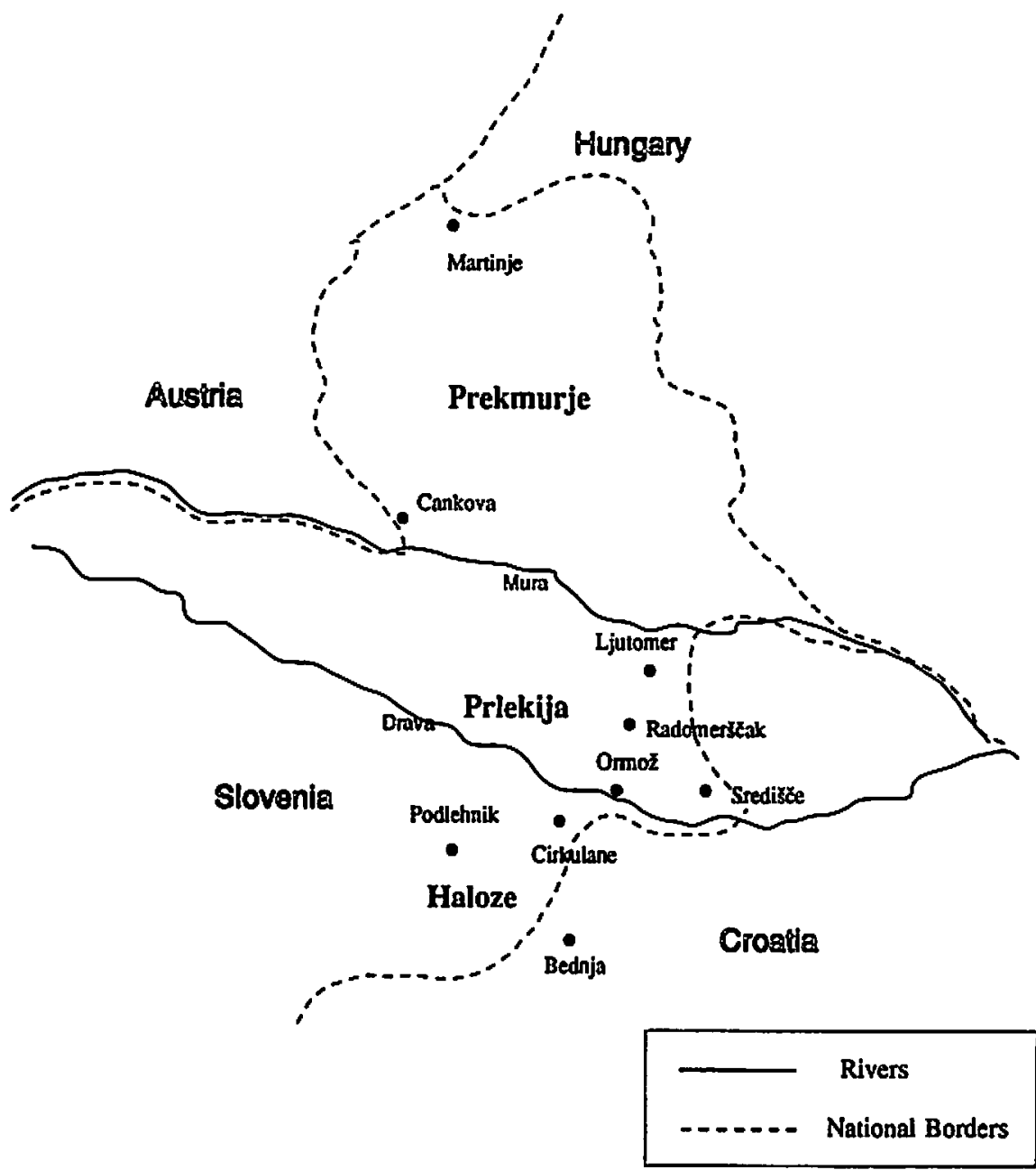


(1) The Common Slavic place of stress is maintained and the reflex of both long and short vowels is in most cases neutralized in favor of length. The following types obtain: (a) a weak jer in the first syllable ceded the stress to the following syllable and was subsequently lost, e.g., spỳeved 'confession' (303), zlỳ.ežil 'folded' (masc. sg.) (329); (b) the n'a.bro type, e.g., nà:obrol 'gathered' (321), vè.yžgol 'kindled' (317), vè.yžgole 'kindled' (neut. sg.) (317), vè yžgot 'to kindle' (sup.) (317), zi:ebrol 'chose' (293);18 (c) words with a long vowel in the first syllable and an open second syllable, e.g., li:epe 'beautfiul' (312), mà:se 'meat' (288), si :ene 'hay' (288), si:eno 'son' (acc./gen. sg.) (323). There is some variation between advanced and non-advanced forms if the first syllable is short and the second open and either long or short: (d) initial stress is maintained and the stressed vowel is short, e.g., dèmo 'at home' (319), ellevo 'lead' (286), ima 'name' (288), kelo $(286,289)$; (e) initial stress is maintained and the stressed vowel is long, e.g., jy :eke 'eye' (299), ma:do 'of honey' (328); ( $f$ ) the shift has taken place and the stressed syllable is long eky'elu 'around' $(319,326)$, nojy:epok 'backwards, wrong' (320). Jedvaj notes that the acc. sg. fem. of the type ny:egu/negò. $u$ 'leg,' with a short vowel in the initial syllable, may be stressed either on the first or second syllable, e.g., ky.esu 'scythe,' gỳ:eru 'mountain,' di:esku 'board,' sni:ehu 'daughter-in-law' as well as kesò u, gerò u, deskò:u, snehò u (302).

(2) In forms with a short initial syllable and a closed second syllable, circumflex advancement has taken place and the stressed syllable is long, regardless of the quantity of Common Slavic quantity of the first or second syllable, e.g., (a) from a short vowel in the first syllable onto a long vowel in the second: ebd:od 'horsefly' (296), eblà:ok 'cloud' (286, 296), erà :ot 'to plow' (sup.) (310), gelò.ub 'pigeon' (288), pečà.l 'began' (masc. sg.) (329), però:ut 'wing' (303); (b) short onto short: beja:ol, bejà:oli sa 'was, were afraid' (masc. sg., masc. pl.) (315) kekỳ:eš 'hen' (283), kekỳ:et 'rooster' (283), vesà:l 'happy' (305), zopè:r 'closed' (287, 385); (c) long onto long: plotè :it 'to pay' (sup.) (315), syše.it 'to dry' (sup.) (310); (d) long onto short: devà:r 'brother-in-law' $(288,296)$, zopè:r 'he closed' $(287,325)$. It is not possible to tell whether the relevant phonological condition for advancement is the closedness of the second syllable, since open second syllables in words longer than two syllables also have advancement, e.g., geld.ubi 'pigeons' (295),

${ }^{18}$ Unlike in the Prekmurje dialect, the n'a:bro type has not spread analogically to the I-participle with a strong jer in the second syllable, e.g., zope.r 'he closed' $(287,325)$, rozde.r 'he tore up' (287). 
jasd:ni 'autumn' (gen. sg.) (307), pečà:li 'began' (masc. pl.) (327). In each of these instances there exists the possibility of leveling based on a form with a closed syllable, e.g., gelòub, pečà $l \longrightarrow$ gelòubi, pečdili. However, adverbial forms, such as eky:elu, nojy:epok, in which the advancement could not have been introduced by leveling, suggest that in words longer than two syllables the presence of a third syllable (rather than a closed second syllable) is the controlling factor.

\section{Prlekija 2: Središče}

The dialect of Središče, located in southeastern Prlekija, is said to have affinities with the Kajkavian Medjimurje dialects to the east (Kolarič 1956: 163). Ozvald was apparently the first to note that Središč fails to have consistent circumflex advancement: "[...] with regard to the progressive shift of accent, literary Slovene and the Središče dialect do not agree. Examples: okô, mesô, kolô, srcê, na okô, po vodô sound like this in the Središ̌e dialect òko, mẹ́so, kòlo, sirce ${ }^{19}$. We see that here Središce is closer to Sltokavian than to standard Slovene. There is no reason to look for an independent development in Središče accentuation, but one should instead view this and many other peculiarities of Središče accentuation as the influence of nearby Croatian accentuation" (Ozvald 1897-98: 43). ${ }^{20}$ Nevertheless, on this particular point, Središče behaves in a structurally predictable way. Let us review the evidence that Ozvald provides:

(1) In the n'a:bro type, the stress is found in the initial syllable and the Common Slavic short vowel (no long vowels in this type are attested) remains short-stressed: p'odro (1898: 90), p'ožro (1898: 90). The form 'odkot 'whence' (1898: 62) may also belong here. As in

19 In each of Ozvald's four works (known to me) on the Sredisce dialect, he used a different set of symbols for the phonetic transcription of vowel qualities. Although there is internal logic within each of the four texts (three manuscripts and a published article), there is little continuity from one text to another. The reader is therefore wamed not to take the vowel qualities as very meaningful. At the moment, only two things are unambiguous about Ozvald's notation: place of stress and vowel quantity (acute = long, grave - short), the distribution assumed in further citations of Ozvald's material. The author is currently undertaking an analysis to make sense of Ozvald's material and intends to publish the results as a separate article.

${ }^{20}$ I am grateful to Mrs. Sonja Horvat (Dialectological Section, Slovene Academy of Arts and Sciences) for providing me with copies of Ozvald's manuscripts 1895.96 and 1897-89; and to Mr. Marko Kranjec (Slavic Library, University of Ljubljana) for obtaining and providing access to the original of Ozvald 1898. 
Prekmurje, an initial weak jer ceded stress to the following syllable, which has becomes long, e.g., sp'o.vet 'confession' (1904: 5, 15).

(2) If the stressed vowel was short in Common Slavic or belongs to a prefix and the second syllable is open, the stress remains on the first syllable and the vowel is short-stressed: 'ime 'name' (1897-98: 30), 'oko 'eye' (1897-98: 30), p'äro 'feather' (1895-96: 27), pr'oso 'millet' (1897-89: 30), z'apoved 'order, command' (1897-98: 30); n'oči 'night' (gen. sg.) (1897: 30), 'oči 'eyes' (nom./acc. pl) (1898: 47).

(3) If the stressed vowel was long in Common Slavic and the second syllable open, the stress remains on the first syllable and the vowel is long-stressed: bl'å:go (1897-89: 30), m'e:so 'meat' (1904: 6), t'e:lo 'body' (1904: 5), v'u:ho (1895-96: 16), z'a:to 'because' (1898: 61); br'e:ga 'hill' (gen. sg.) (1898: 21).

(4) If the second syllable was closed, circumflex advancement took place regardless of the Common Slavic quantity of the first or second syllable. The second (stressed) syllable is realized as long, without regard to the Common Slavic quantity: dok'o:t 'whither' (1898: 62), gosp'o.t 'Mister' (1904: 15), päp'e:l 'ashes' (1904: 12), skop'o:st 'niggardliness' (1898: 30), vä̌x'e.r 'evening' (1898: 30); gol'o.p 'pigeon' (1904: 6); kos'i.t 'to mow' (supine) (1897-98: 34), lov'io ${ }^{21}$ 'hunted' (masc. sg.) (1898: 88), obl'å:k 'cloud' (1898: 30), or'å:l 'plow' (1904: 12); bud'it. 'to awaken' (supine) (1897-98: 34), suš'io 'dried' (masc. sg.) (1898: 88), sušti:lo 'dried' (neut. sg.) (1895-96: 21).

Two rules thus account for the presence versus absence of circumflex advancement in Središče: (1) if the first syllable was a weak jer before a full vowel, the stress is ceded to the following syllable and the jer subsequently lost; (2) if the second syllable is long and/or closed, the stress is advanced. In all other positions, initial stress remains. The presence vs. absence of circumflex advancement is a structural matter and it would thus be impossible to ascribe the discrepancies with other Slovene dialects, as Ozvald had assumed necessary, as a result of external influence.

\section{Conclusion}

The phenomena described above in eastern Slovene and western Kajkavian, though seemingly heterogeneous, appear to have properties in common. Each area displays a set of words for which initial stress may be interpreted as an archaism. This implies that the

21 Before the ending $-o(<*-18)$ the vowel is predictably shortened, cf. suštio (1898: 88), sušit:o (1895-96: 21 ). 
TABLE I. CIRCUMFLEX ADVANCEMENT HIERARCHY

\begin{tabular}{|c|c|c|c|c|}
\hline $\begin{array}{l}\text { Syllable } \\
\text { Weight }\end{array}$ & $\begin{array}{l}\text { Common } \\
\text { Slavic }\end{array}$ & $\begin{array}{l}\text { Standard } \\
\text { Slovene }\end{array}$ & Prekmurje & Haloze \\
\hline CVCbC... & $\begin{array}{l}\text { sì-/zì-ž̀bga:/b, } \\
\text {-a:li:; } \\
\text { nà:bbra:lz, } \\
\text {-a:li: }\end{array}$ & $\begin{array}{l}\text { sežgà:u, -a:li, } \\
\text { nabrà:u, -a:li }\end{array}$ & $\begin{array}{l}\text { z'c:žgo, -åli; } \\
\text { l'a:bro, -îli }\end{array}$ & z'ẹbrali \\
\hline (C) VC & oko & olọ: & ox'ou & of'o: \\
\hline $\mathrm{CV}: \mathrm{CV}$ & mę:so, sè̃:no & mesọ:, senọ: & mes'ou, sen'ou & mes'o: \\
\hline $\mathrm{CV}: \mathrm{CV}:$ & $\begin{array}{l}\text { rò:kQ:, lés:sa:, } \\
\text { brè̃:ga:, pì:li:, } \\
\text { nà:pi:li: }\end{array}$ & $\begin{array}{l}\text { rolọ̀:/ró:ko, } \\
\text { lesà:, bregà:; } \\
\text { (pì:li), napi:li }\end{array}$ & $\begin{array}{l}\text { rok'ou, les'a: } \\
\text { breg'a:, pil'i: }\end{array}$ & lis'a: \\
\hline CVCV: & $\begin{array}{l}\text { nògo:, kòsti:, } \\
\text { pèči: }\end{array}$ & $\begin{array}{l}\text { nog̀o:/nó:go, } \\
\text { kostì:, peči: }\end{array}$ & nog'ou, kost'i: & kost'i: \\
\hline CVCVC & $\begin{array}{l}\text { kòkošb, } \\
\text { vèčerb, jèsenb }\end{array}$ & $\begin{array}{l}\text { kokọ:š, vecẹ:r, } \\
\text { jesệ:n }\end{array}$ & kok'ouš & več'e:r \\
\hline CVCV:C & gòlQ̨:bb & golọ:b & gol'oub & gol'ọ:p \\
\hline $\mathrm{CV}: \mathrm{CV}: \mathrm{C}$ & $\begin{array}{l}\text { sù:šitţ, } \\
\text { bù:di:ţ }\end{array}$ & suši:t & sis'i:t & suš̉itt \\
\hline
\end{tabular}


Prlckija 1: Bednja

Radomerščak

z'çbrali

vè:yžgol

'oho

m'E:so sino

pil'i:

rò:uku

br'e:ga

rọ:kọ

pec' 'i:

jes'ẹ:n

gol'o:p

*siši:t p'ožro

Prlckija 2: Truropolje Središče

prèbral

\begin{tabular}{|lll} 
jỳche & 'oho & óko \\
sì:ene & m'E:so & sẹino \\
rò:uku & br'e:ga & rọ̀:ko
\end{tabular}

negò:u/nỳ:egu p'äči nògo

kòkoš

gò:lop

*sù:šit 
innovation of advancement must have been restricted in certain ways in these dialects. Table I (pp. 86-87) summarizes the facts discussed here and illustrates the proposal that circumflex advancement-as many other inter-syllabic stress shifts in the history of South Slavic-was conditioned by the relative weights of the stress-ceding and stress-receiving syllables. The progress of the innovation is enclosed in the double line. Standard Slovene is unrestricted with respect to the innovation (a fact which has given the impression that circumflex advancement was an all-or-nothing phenomenon). Prekmurje, Haloze and Radomerščak Prlekian fail to have advancement if the second syllable contained a weak jer (n'a:bro, -dili, z'ẹbrali). Bednja Kajkavian shares the retention of stress in this same environment (vè.yžgol); retention is also found in words with an open second syllable (jỳ:eke, si:ene, rò uku), unless the first syllable was a Common Slavic short vowel and the second a long vowel, in which case there is variation between retention and advancement (negò:u/nỳ:egu). Središče Prlekian appears to have a further restriction in this environment ( $\left.p^{\prime} \ddot{a} \bar{c} i\right)$. Turopolje Kajkavian (after Šojat 1982) illustrates a dialect that has the restriction in all environments.

As is clear from the material presented above, a set of related phenomena can be detected in a strip of territory running roughly along the present Slovene border from the Raba valley in Porabje (Hungary) through Prlekija and Haloze. This places the stress retentions on the northeastern periphery of Slovene, suggesting that the phenomena described are indeed archaisms. The main lines of development sketched here make sense when both the structural motivation (the advancement hierarchy, outlined above) and the geography are taken together. ${ }^{22}$ To conclude, the analysis shows that weak jers were still present in this peripheral area at the time of circumflex advancement. Moreover, the advancement hierarchy in the northeast, considered together with similar phenomena in the northwest, suggests that circumflex advancement took place in a hierarchical, chronologically ordered fashion throughout the Slovene dialects, and failed to become fully implemented as it reached the northeast.

The University of Kansas

22 Naturally, the precise location of isoglosses is yet to be determined and the progress of advancement in the hierarchy, especially in Haloze and Prlekija, will perhaps be modified as more reliable material becomes available. 


\section{BIBLIOGRAPHY}

Bajec, Anton. 1921-1922. "O prvotnem slovenskem naglasu $\wedge \vee$ rezijanskem narečju," Casopis za slovenski jezik. književnost in zgodovino 3: 40-42.

Greenberg, Marc L. 1987. "Prozodične možnosti v slovenskem knjižnem jeziku in slovenskih narečjih," Slavistična revija 35/2: 171-186.

- 1990. A Historical Analysis of the Phonology and Accentuation of the Prekmurje Dialect of Slovene. Unpublished Ph.D. dissertation, University of California at Los Angeles.

- 1993. "Glasoslovni opis treh prekmurskih govorov in komentar $k$ zgodovinskemu glasoslovju in oblikoglasju prekmurskega narečja," Slavisrična revija 41/4: 465-487.

Gregorič, Jožc. 1983. Delač. Ljubljana: Znanstvenoraziskovalni center Inštituta za slovenski jezik Frana Ramovša, Slovenska akademija znanosti in umetnosti (unpublished dialect description for the Slovenski lingvistični atlas).

Jaksche, Harald. 1965. Slavische Akzentuation II: Slovenisch. Wiesbaden: Otto Harrassowitz.

Jedvaj, Josip. 1956. "Bednjanski govor," Hrvatski dijalektološki zbornik 1: 279-330.

Junković, Zvonimir. 1972. Jezik Antuna Vramca i podrijetlo kajkavskoga dijalekta. Diahronska rasprava [- Rad JAZU 363, Odjel za filologiju 17]. Zagreb: JAZU.

Kolarič, Rudolf. 1956. "Središka govorica in spodnjeprleški govor," Slavistična revija 9: 162-170.

-1964. "Haloški govor," Prace filologiczne 18/2: 395-401.

Kortlandt, F. H. H. "The Slovene neo-Circumflex," The Slavonic and East European Review 54/1: 1-10.

Križman, Mirko. 1987. "Jezikovna sedanjost v Radgonskem kotu s sociolingvističnih vidikov," Casopis za zgodovino in narodopisje 58 (-23)/2: 173-215.

Lencek, Rado. 1982. The Structure and History of the Slovene Language. Columbus: Slavica.

Ozvald, Karol. 1895-1896. Nekoliko o razrečju Središkem. University of Graz: Unpublished seminar paper. (Ms. 49 pp.)

1897-1898. Besedni naglas v središkem narečju. University of Graz: Unpublished seminar paper. (Ms. 44 pp.)

- 1898. Morfologija središkega narečja s posebnim ozirom na slovensko dialektologijo. University of Graz: Unpublished seminar paper. (Ms. 94 pp.)

. 1904. "Zur Phonetik des Dialektes von Polstrau," 44. Jahresbericht des. k. k. Stadtsgymnasiums in Görz:1-16. 
Pável, Ágoston. 1909. A vashidegkúti szlovén nyelvjárás hangtana. Budapest: Kiadja a m. tud. Akademia.

- 1917. "Vend szöveggyüjtemény s az eddigi gyüjtések törtenete.," Nyelvtudomány 6/3: 161-187.

— 1918. "Vend szöveggyüjtemény s az eddigi gyüjtések története," (cont.). Nyelvtudomány 6/4: 263-282.

Ramovš, Fran. 1929. "O premiku akcenta v tipih zvězdà, ženà in mgglă v slovenskem jeziku," Lud slowiański 1/1A: 48-61.

—. 1935. Historična gramatika slovenskega jezika VII. Dialekti. Ljubljana: Akademska založba.

— 1950. "Relativna kronologija slovenskih akcentskih pojavov," Slavistična revija 3/1-2: 16-23.

Rigler, Jakob. 1972. "O rezijanskem naglasu," Slavistična revija 20/1: $115-126$.

- 1986 (1973). "Smeri glasovnega razvoja v panonskih govorih," in Razprave o slovenskem jeziku (ed. Franc Jakopin), 116-138. Ljubljana: Slovenska matica. (Originally published in Studije o jeziku in slovstvu, pp. 113-128.)

Stang, Christian S. 1957. Slavonic Accentuation (- Norske Videnskaps-Akademi i Oslo 1. Hist.-Fil. Klasse 3). Oslo: W. Nygaard.

Stankiewicz, Edward. 1984-1985. "The dialect of Resia and the "Common Slovenian' accentual pattem," Zbornik Matice srpske za filologiju i lingvistiku: 719-725.

_. 1986 (1966). "The Common Slavic prosodic pattern and its evolution in Slovenian," in E. Stankiewicz, The Slavic Languages. Unity in Diversity: 35-45. Berlin: Mouton de Gruyter. (Originally published in International Journal of Slavic Linguistics and Poetics 10: 29-38).

\$ojat, Antun. 1982. "Turopoljski govori," Hrvatski dijalektološki zbornik 6: 317-493."

Vermeer, Willem. 1979. "Innovations in the Kajkavian dialect of Bednja," Dutch Contributions to the Eighth International Congress of Slavists. Zagreb, Ljubljana, 1978 (ed. Jan M. Meier), 347-381. Lisse: Peter de Ridder.

1987. "The treatment of the Proto-Slavic falling tone in the Resian dialects of Slovene," in Dutch Studies in South Slavic and Balkan Linguistics (- Studies in Slavic and General Linguistics 10): 275-298. Amsterdam: Rodopi.

Zorko, Zinka. 1989. "Govor vasi Zletinci (Sicheldorf) v avstrijskem Radgonskem kotu.," Slavistična revija 37/1-3: 241-251.

- 1991. "Vzhodni haloški govori," Nemzetk@zi szlavisztikai napok 4: 51.69 . 
1992. "Prleško narečje v Radomerščaku, rojstnem kraju F. Miklošiča," Miklošičev zbornik: Mednarodni simpozij v Ljubljani od 26. do 28. junija 1991 (ed. Jože Toporišič) [0 Obdobja 13], 463-476. Ljubljana: SAZU, University of Ljubljana; Maribor: University of Maribor.

- 1993. "Daljšanje akuta v severovzhodnih slovenskih narečjih," Slavistična revija 41/1: 193-207.

\section{POVZETEK}

\section{POMIK CIRKUMFLEKSA V PREKMURSCINI IN DRUGOD}

Razprava obravnava pomik praslovanskega cirkumfleksa $v$ slovenščini in kajkavščini, s posebnim ozirom na razvoj $v$ prekmurščini in sosednjem prleškem, haloškem in kajkavskih narečjih. Analiza prekmurskih in drugih vzhodnoslovenskih in kajkavskih podatkov pokaže naslednje: (1) V omenjenih narečjih so morali šibki jeri pred pomikom cirkumfleksa še obstajati. (2) Naglasni pomik je stvar naglasne privlačnosti, temelječe na teži zloga. Iz tega sledi, da je bil pomik cirkumfleksa dinamičen proces, ki je potekal v praslovenščini in delu kajkavščine, in ne jasno zamejena, naenkrat zaključena samoslovenska inovacija. 